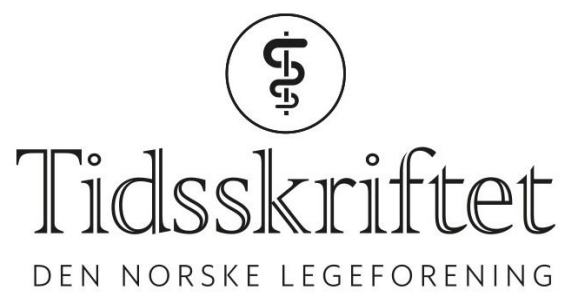

\title{
Best å igangsette fødsel ved overtidig svangerskap
}

FRA ANDRE TIDSSKRIFTER

KETIL SLAGSTAD

Tidsskriftet

En studie der man sammenliknet fødselsinduksjon ved overtidig svangerskap mot avventende behandling, måtte avbrytes på grunn av flere dødfødsler ved avventende behandling. 


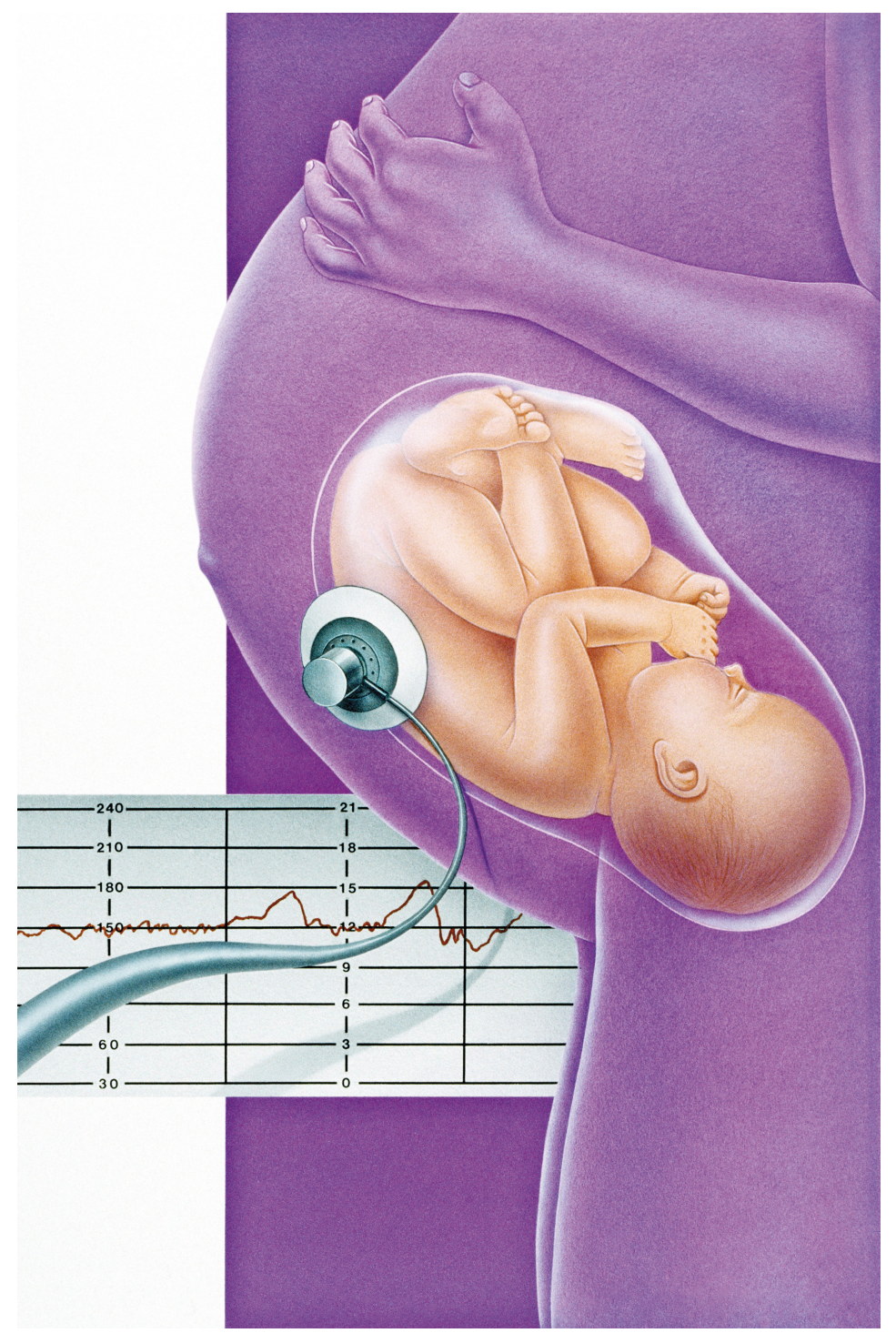

Illustrasjon: Science photo library/ NTB Scanpix

Risikoen for perinatale komplikasjoner øker ved overtidige svangerskap, dvs. f.o.m. dag 294 eller uke $42+o$. For svangerskap mellom uke $41+o$ og $42+o$ er det varierende praksis i ulike land for å igangsette fødsel, og dokumentasjonen er mangelfull.

I en ny svensk studie ble gravide kvinner med lavrisikosvangerskap og ultralydverifisert svangerskapslengde mellom uke 40+6 til 41+1 randomisert til igangsettelse eller avventende behandling og igangsettelse i uke $42+0$ (1). Studien ble startet i mai 2016, men måtte stoppes før tiden i oktober 2018 pga. økt perinatal dødelighet i kontrollgruppen, henholdsvis seks (hvorav fem døde intrauterint) og ingen perinatale dødsfall i de to gruppene. Andelen som fødte spontant var henholdsvis 14,1 \% og 66,7\%.

- Denne studien er interessant, har høy kvalitet og er utført i et skandinavisk land med sammenliknbar fødselshjelp og keisersnittfrekvens som i Norge. Likevel må resultatene tolkes med forsiktighet, sier Tilde Østborg, som er overlege ved Kvinneklinikken, Stavanger universitetssjukehus. I gruppen som ble randomisert til avventende behandling, fikk kun kvinner i Stockholm, som utgjorde drøyt 40 \%, oppfølging i form av trivselskontroll med kardiotokografi (CTG-undersøkelse) og ultralydunders $ø$ kelse, og det var ingen tilfeller av intrauterin fosterdød.

- Alle de fem tilfellene av intrauterin fosterdød forekom ved institusjoner hvor en slik trivselskontroll ikke ble gjort. Forekomsten var høyere enn det man kjenner til fra Norge og internasjonale studier, sier hun.

- Ifølge den norske veilederen i fødselshjelp skal trivselskontroll tilbys alle kvinner i uke 41, og alle skal tilbys induksjon mellom uke $41+3$ og $41+6$. Kvinner som ikke induseres, bør 
følges med ultralyd og kardiotokografi hver 2.-3. dag, sier Østborg.

- Forfatterne fant ingen forskjell i forekomst av keisersnitt eller operativ vaginal forløsning i gruppene. Vi kan dermed stille spørsmål om gevinsten ved spontan fødselsstart er verdt den potensielle risikoen, sier Østborg, som sier at alle kvinner uansett bør få grundig og nyansert informasjon om behandlingsalternativer ved overtidig svangerskap.

\section{LITTERATUR:}

1. Wennerholm U-B, Saltvedt S, Wessberg A et al. Induction of labour at 41 weeks versus expectant management and induction of labour at 42 weeks (SWEdish Post-term Induction Study, SWEPIS): multicentre, open label, randomised, superiority trial. BM] 2019;367: 16131. [PubMed][CrossRef]

Publisert: 6. februar 2020. Tidsskr Nor Legeforen. DOI: 10.4045/tidsskr.20.0oo6

(C) Tidsskrift for Den norske legeforening 2020. Lastet ned fra tidsskriftet.no 